\title{
Effect of Bureau De Change Establishment on the Stability of Exchange Rates in Nigeria
}

\author{
Umar Abbas Ibrahim, $\mathrm{PhD}^{1} \quad$ Aisha Muazu ${ }^{2}$ \\ 1.Department of Business Administration, Nile University of Nigeria, Abuja \\ Abbas.ibrahim@nileuniversity.edu.ng \\ 2.Department of Business Administration, Nile University of Nigeria, Nigeria
}

\begin{abstract}
The purpose of this study is to examine the effect of Bureau de change establishment on the stability of the exchange rate in Nigeria. Ex post-facto and correlation research designs are employed for this study. The sample relied on for the purpose of this work was for the period from 2008-2018. The study relies on secondary data sources such as books, journals, magazines, newspapers, internet, speeches, and document from CBN, NSE and Bureau for public enterprises. The data estimation technique used was ordinary least squares. The findings of the study revealed that the bureau de change establishment impact the stability of the exchange rate in Nigeria. The result indicated that is the long-run relationship between Bureau De change and stability of the exchange rate. The study recommended that participants in the foreign exchange market should undertake forward transactions to serve as an insurance cover (shield) for their spot transactions. The exchange rate of the bureau de change should be closely monitored by monetary authorities to reduce the gap between these rates and the official rates. The government should adopt measures that would bring down the exchange rate of the naira to a US dollar so that Nigerian producers who make use of imported raw materials can continue in business.
\end{abstract}

Keywords: Bureau De Change, Exchange Rate, Stability, Monetary, Naira.

DOI: $10.7176 / \mathrm{EJBM} / 12-6-01$

Publication date: February $29^{\text {th }} 2020$

\subsection{INTRODUCTION}

The significance of a stable exchange rate to the sustainable development of developing economies is well recognized. Anigbogu and Okoye (2014) noted that exchange rates have been highly unstable in Africa especially since the move to a floating exchange rate system with negative consequences for trade, investment, and growth. Nigeria for example practiced a fixed exchange rate before 1986, but she embraced flexible exchange rate policy afterward. As a result, the official Naira exchange rate was allowed to float, within a pre-specified band, in relation to other currencies thereby allow changes within the band to be determined by market forces of demand and supply. Some of the policies employed to guarantee exchange rate stability include among others: second-tier foreign exchange market, bureau de change, independent foreign exchange market, inter-bank foreign exchange market, the enlarged foreign exchange market, and Dutch auction system (DAS), which comprises the retail and wholesale DAS. The uselessness of each of the policies to achieve sustainable stability in the Nigerian exchange rate led to the adoption of another.

A bureau de change is a business that, in competition with other related businesses, makes its profit by buying foreign currency and then selling the same currency at a higher exchange rate. The exchange rates charged at the bureau are generally correlated with the spot prices accessible for large interbank transactions and are accustomed to ensure a profit. The rate at which a bureau will buy currency varies from that at which it will sell it; for every currency, it trades both will be on display, generally in the shop window (Chamalwa \& Idris 2016).

Nigerian Government through monetary authority has propagated many policies to maintain exchange rate stability (Ali, 2015). This makes transnational trade and investment decisions harder because instability increases exchange rate insecurity and risk. Hence, the exchange rate had risen ominously making it difficult for businesses to endeavor. As a result, the domestic market is harmfully affected, unemployment rose and per capita income abridged.

Changing money at a bureau is often more costly than withdrawing it from an automatic teller machine at one's terminus or paying directly by debit or credit card, but this varies subject to the card issuer and the type of account. Fees from multiple ATM withdrawals should also be considered. Some people may feel uncomfortable carrying a lot of cash and so fancy to use a card and carry token cash for tipping cabs, hotels, and restaurants. Hotels and rental cars many times also need cards for short-term holds (Ajibola and Omotosho 2015).

Some may also prefer to hold foreign currency rather than change it back if they are expecting to return to where it is used. Companies that regularly send employees abroad may in essence act as their exchange by compensating their employees in the local currency and holding the foreign currency. If exchange rates are moderately steady, the fees charged by a bureau may surpass any likely fluctuation and it also makes the company's accountancy easier. 
According to Eze and Okpala (2014), numerous studies have been conducted on bureau de change establishment and the steadiness of exchange rate, most of these studies on exchange rates either focused on the effect of exchange rate instability on trade or growth. Second, the majority of the studies were conducted in a developed economy. This led the researcher to venture into the research. Studies on bureau de change and stability of exchange rate do not provide consistent results and have also reported mixed findings. e.g. the study of Sherman and Morley (2015). This study will, therefore, fill these gaps by examining the effect of Bureau De Change establishment on the stability of the exchange rate in Nigeria. The objective of this paper is therefore to examine the effect of bureau de change establishment on the stability of the exchange rate in Nigeria.

\section{LITERATURE REVIEW}

\subsection{Concept of Exchange Rate}

Musa (2014) describes exchange rates as the prices which currencies trade for each other. It is the value of a foreign currency expressed in terms of domestic or other currencies. Tasiu (2014) describes exchange rates as a vital price in an economy that influences most other prices and indeed, the general price level. The rate of exchange is the official value of a country's monetary unit at a given date or over a given period of time, as expressed in units of local currency per USD and as determined by international market forces or official fiat. It is the price of one nation's currency in terms of another nation's currency continually termed the reference currency.

The term foreign exchange refers to the means of payments for universal transactions. It is made of convertible currencies that are acceptable for the settlement of international trade and other external responsibilities such as interests, profits, dividends and transfers (Yokoyamal, 2015). In the balance of payments, foreign exchange covers economic authorities claim on non-residents in the form of bank deposits, treasury bills, short term, and long term government securities. Foreign exchange also comprises of European currency units, other claims usable in the event of balance of payments needs, non-marketable claims arising from the inter-central bank and intergovernmental provisions without regard to whether the claim is denominated in the currency of the debtor or creditor (Kawaguchi, 2015).

\subsubsection{Bureau De Change}

According to Mgbodile (2014), a bureau de change is often located at a bank, at a travel agent, airport, main railway station or large stores - namely, anywhere that is prospective to be a market for people needing to convert currency. They are particularly prominent at travel hubs, although currency can be exchanged in many other ways both legally and illegally in other venues. Some of the key players include HSBC, Travelex, JPMorgan Chase \& Co., Wells Fargo, and Bank of America.

According to Bonga (2017), the license of a Bureau De Change (BDC) in Nigeria confers on the holder the rights and privileges of an approved buyer of foreign exchange in keeping with the standard of the financial services industry and to generate and maintain public confidence in the sub-sector(CBN). The liberalization opened the market for the operations of private BDCs and authorised dealer BDCs. The operations of these BDCs with Central bank windows are cash operation. Each licensed BDC was required to open a Naira Current Account with an Authorized Dealer of its choice, to buy foreign exchange. A Bureau-de-Change is allowed to purchase foreign exchange from the Central bank through a presentation of the bank's cheque issued by their banks twice a week. Dayyabu (2015) The foreign currencies dealt in by a Bureau De Change shall be derived from private sources or such other sources, including the Interbank foreign exchange market, as the Central Bank of Nigeria shall define from time to time for the purpose of Business Travel Allowance [BTA] and Personal Travel Allowance [PTA]. Selling foreign exchange to BDCs by the Central bank was a major factor in the convergence of the foreign exchange market rates (Okoroafor and Aluko 2013).

A Bureau De Change (BDC) is defined by the Central Bank of Nigeria $(\mathrm{CBN})$ manual as a retail foreign exchange dealer carrying on the business of Personal Travel Allowance (PTA), Business Travel Allowance (BTA), medical and school fees, and also to carrying on inward and outward transfer. So, a BDC is a licensed outfit, normally by the CBN (Adnan and Sulong 2016).

All over the world, there are BDC operators and they play different roles. For instance, the primary role of BDCs globally, according to the Association of Bureau De Change Operators of Nigeria (ABCON), is to ensure forex availability to the critical retail sector of the forex market in terms of supply, to bridge the gap between the official and the parallel market exchange rate (Okpala, 2014). The operators said they have even gone beyond ensuring rate convergence and providing liquidity, to the achievement of the major policy of the CBN, which is exchange rate stability.

Chi, (2015) Before BDCs were allowed in the official foreign exchange market, the apex bank over the years tried many methods to ensure there is the convergence of the exchange rates, but it was not successful. "We have witnessed a different auction system, Retail Dutch Auction, Wholesale Dutch Auction, all these did not deliver the desired result. But in 2006, when all the prescriptions of how to checkmate this problem of spikes in the forex market, the thought of allowing BDCs to come into the official market was considered.

"By then we had a gap of about N50 ranging to N60, but as soon as BDCs came into the official market, 
within one month, the rates converged to a difference of only 50 kobo between the parallel market and the official market. So the BDCs have continued to play that role to the $\mathrm{CBN}$ and even to the government of Nigeria, to ensure that there is the convergence of rates, elimination of spikes in the forex rates and that there is exchange rate stability," he said (Wang, 2015).

Over time, there have been arguments about the role of BDCs. Some even went to the extent of saying the BDCs are no longer relevant. The single exchange market that came in 2014, did not even recognize the role of BDCs. Adelowokan and Adesoye (2015) "That regime did not last because they did not consider the role of the BDCs. But after consistent agitation by the association that there is a need to acknowledge the role of the BDCs and include them, CBN reviewed its stance and offered us what they call the International Money Transfer Operations (IMTO) proceeds. Since then, there have been significant achievements (Oleka 2016).

Table 1: Scheme of Events in Exchange Rate Management in Nigeria

\begin{tabular}{|c|c|c|c|}
\hline $\mathbf{s} / \mathbf{n}$ & Year & Event & Remark \\
\hline 1 & $\begin{array}{l}1959- \\
1967\end{array}$ & $\begin{array}{l}\text { Fixed Parity Solely with the British } \\
\text { Pound Sterling }\end{array}$ & Suspended in 1972 \\
\hline 2 & $\begin{array}{l}1968- \\
1972\end{array}$ & $\begin{array}{l}\text { Included the US dollar in the parity } \\
\text { exchange }\end{array}$ & $\begin{array}{l}\text { Aftermath of the } 1967 \text { devaluation of the pound and the } \\
\text { emergence of a strong dollar. }\end{array}$ \\
\hline 3 & 1973 & $\begin{array}{l}\text { Revert to fixed parity with the British } \\
\text { Pounds }\end{array}$ & Devaluation of the US dollar \\
\hline 4 & 1974 & Parity to both pounds and dollars & $\begin{array}{l}\text { To minimize the effect of the devaluation of the } \\
\text { individual currency }\end{array}$ \\
\hline 5 & 1978 & $\begin{array}{l}\text { Trade (import) - Weighted basket of } \\
\text { currency approach. }\end{array}$ & $\begin{array}{l}\text { Tied to seven currencies; British Pounds, US Dollars, } \\
\text { German Mark, French Franc, Japanese Yen, Dutch } \\
\text { Guilder, Swiss Franc. }\end{array}$ \\
\hline 6 & 1985 & Reference on the dollar & To prevent arbitrage prevalent in the basket of currencies \\
\hline 7 & 1986 & $\begin{array}{l}\text { Adoption of the second tier foreign } \\
\text { exchange market }\end{array}$ & Deregulation of the economy \\
\hline 8 & 1987 & $\begin{array}{l}\text { Merger of the first and second tier } \\
\text { markets }\end{array}$ & Merger of rates \\
\hline 9 & 1988 & $\begin{array}{l}\text { Introduction of the interbank foreign } \\
\text { exchange market }\end{array}$ & Merger between the autonomous and the FEM rates \\
\hline 10 & 1994 & Fixed Exchange rate & Regulate the economy \\
\hline 11 & 1995 & $\begin{array}{l}\text { Introduction of the Autonomous } \\
\text { Foreign Exchange Market (AFEM) }\end{array}$ & Guided Deregulation. \\
\hline 12 & 1999 & $\begin{array}{l}\text { Re-introduction of the inter-bank } \\
\text { foreign exchange market (IFEM). }\end{array}$ & $\begin{array}{l}\text { Merger of dual exchange rate, following the abolition of } \\
\text { the official exchange rate from January } 1^{\text {st }} \text {. }\end{array}$ \\
\hline 13 & 2002 & $\begin{array}{l}\text { Re-introduction of the Dutch Auction } \\
\text { System (DAS). }\end{array}$ & $\begin{array}{l}\text { Retail DAS was implemented at first instance with CBN } \\
\text { selling to end-users through the authorized users (banks) }\end{array}$ \\
\hline 14 & $\begin{array}{l}2006 \\
2010\end{array}$ & Introduction of Wholesale DAS & Further liberalized the market \\
\hline
\end{tabular}

Source: Central Bank of Nigeria Bullion (2006)

2.1.2 Evolution of Bureau -de Change in Nigeria

According to the Central Bank of Nigeria (2015) Bureau de Change arose due to the need for retail foreign exchange dealers who can conduct the business of Personal Travel Award (PTA), Business Travel Award (BTA), medical and school fees, and also transfers both in-and out-of-pocket. Hence, the CBN licensed BDC for these activities. They are different BDC operators across Nigeria and they play different positions. For example, according to the Association of Bureau De Change Operators of Nigeria (ABCON), the BDCs have the primary role worldwide in ensuring forex availability for delivery to the vital retail sector of the forex market in order to bridge the gap between the official exchange rate and parallel market rate. The operators usually go beyond the promise of market stabilization and the provision of liquidity to achieve the CBN's main exchange-rate stability policies. The Central Bank has over the years tried several ways to ensure convergence of exchange rates, but it has not been successful, according to Alhaji Aminu Gwadabe (National Chairman of the group). According to the Chairman, "We have seen numerous auction schemes, Retail Dutch auction, Wholesale Dutch auction, all of which have not produced the desired result...But in 2006, when all the recommendations on how to address this question of fluctuations in the forex market were accepted, BDCs needed to enter into the official business. The chairman further notes that "Before that time, we had an N50 disparity of around N60, but as soon as BDCs reached the official sector, the prices converged within the month to a discrepancy of only 50 kobos between the parallel and the official market $(\mathrm{CBN}, 2015)$. Indeed, the BDCs continued to play their role for the $\mathrm{CBN}$, even for the government of Nigeria, to ensure rate convergence, the elimination of forex spikes and the stability of the exchange 
rate. Overtime, arguments have been made about the position of BDCs. Others even said that the BDCs are no longer relevant. In 2014, the single exchange market did not even recognize the role of the BDCs (CBN, 2015).

2.1.3 Challenges of Exchange Rate Stability, and Exchange Rate Management in Nigeria

From the 1980s onwards Nigeria's monetary authorities, as well as World Bank / IMF(International Monetary Fund) experts, broadly agreed that Nigeria's major macroeconomic problem is linked to an unrealistic Naira exchange rate regime. The overvalued naira discourages exports by rendering them relatively more expensive and by cheaper imports. Another problem is that over-valued naira threatens to hinder efficient use of resources, promote capital flight and make cheap imports, thus rendering Nigeria reliant on imports among other plagues. This realization's importance prompted the search for a realistic value for the naira, which remained the essential aspect of a number of reform issues. The SAP(Structural Adjustment Programme) directed modernization and, eventually, the National Economic Empowerment and Development Strategy (NEEDS) have modified their acronyms. Nevertheless, the essential ingredient remains the accomplishment of an over-valued realistic value for naira. The results include high unemployment, inequality, and rising growth. The foreign exchange market is difficult to predict. Such foreign investment is influenced by the weak currency market program. The unstable system causes disinvestment (Emenike \& Aleke, 2012).

The SFEM (Second-Tier Foreign Exchange Market) was and is a framework for deciding the true value of Naira via the market forces of demand and supply. Nigerian currency value is explicitly calculated in compliance with the exchange rate management arrangements. The key objectives of the exchange rate strategy in Nigeria are to preserve the domestic currency's foreign value, sustain a favorable position of external reserves and protect the external balance. The need for internal equilibrium and the overarching objective of macroeconomic stability will not be sacrificed. This is the problem with the management of exchange rates in Nigeria (Taiwo, 2013). The inability to accurately determine the level of the naira exchange rate which would guarantee that the internal and external equilibrium would be maintained concurrently on a permanent basis was indeed another challenge for exchange rate stability for Nigeria.

\subsubsection{Degree of Success of the Exchange Policy}

A key question as regards exchange rate management in Nigeria is: to what degree was Nigeria able to achieve the goals of the exchange policy? The exchange rate strategy implemented at a particular point relies on the goals that the authorities are to meet. SFEM was and continues to be a macroeconomic policy aimed at improving Nigerian economic efficiency and productivity. The extent to which this was achieved gives space to contend. Therefore, an equilibrium exchange rate is reached free of volatility and adjustments, if a given degree of exchange rate makes it possible for an economy to attain the internal and external balances without implementing trade and currency barriers and policies that are contradictory to international standards which are subjective. Such intervention contributes to retaliatory effects, which threaten macroeconomic policy goals and priorities.

A cursory study of the Nigerian exchange rate regimes shows that exchange rates have dual structures, that is, set and variable systems, as applied in Nigeria. The year 1960-1986 saw a fixed exchange rate system period. The system's failure to achieve the major exchange rate policy objectives led to a reversal of the policy trend in 1986. This was the float of the naira. The flexible system lasted until, including, 1994, which was a historic year for the reintroduction of the fixed exchange rate. The exchange rate of 1970-1975 was therefore set by Grobar (1993) at 0.7142 to 0.159 , an inflation rate of 13.8 percent for the same period and up to 33.9 percent in 1975 , and a real nominal exchange rate of 99.9 percent in 1970 and of 100.4 percent in 1975. Effective GDP growth fell from $29.8 \%$ in 1970 to-3\% in 1975 . The volume and movement of imports and exports were never omitted, but unprecedented rises for exports were reported from N885.4 million to N4925.5 million respectively in 1970 to 75 million.

For imports, 1970 reported 756.4 and in 1975 increased to 3721.5. As further shown in Table I below the rate of inflation in 1982 declined to 7.7 percent, it rose respectively to 23.2 percent and 39.6 percent in 1983 and 1984 . There have also been declines in 1985 (55.5\%), 1987 (10.2\%) and $1988(38.3 \%), 1989(40.9 \%), 1993(54.1 \%)$ and $1997(60.2 \%)$ and consistent rises (Bakare, 2011). The exchange rate and other factors often revealed an interesting situation. Fluctuations in the exchange rate were reported between 1976 and 2002. The import, production and development patterns of real GDP showed volatility similarly and preserved high levels of uncertainty. In fact, a table study shows instances of Vis-a-vis variance uncertainty in macroeconomic variables.

\subsection{Theoretical Framework}

The study utilizes the balance of payment theory to underpin the study. The theory was propounded and stretched out by Krueger (1969). The theory stipulates that under free exchange rates, the exchange rate of the currency of a country depends upon its balance of payment. Another key assumption of the theory is that the price of foreign money is decided by the competitive powers of demand and supply on the exchange market. The international value of a country's currency will, therefore, rely on the currency demand and supply. The theory postulates that that demand and supply forces are determined by different items in a country's balance of payments. According to the principle, a balance of trade deficit corresponds to a reduction or weakening in the exchange rate, whereas a 
balance of payments increases the exchange reserves, resulting in an increase of the domestic currency price in terms of foreign currency.

The theory also argues that a country's deficit balance of payments means that foreign exchange production exceeds its availability. Consequently, the price of foreign currency in domestic currency must increase, i.e. the domestic currency exchange rate must decline. On the other side, a surplus in a country's balance of payments means that a foreign country has a higher demand for home currency than the supply sufficient. As a result, the price of the domestic currency increases with regard to foreign money, i.e. the exchange rate improves.

The study of Bakare (2011) further lends credence to the theory. The author argues that a favorable balance of payments raises the exchange rate, while an unfavorable balance of payments reduces the exchange rate. Thus the theory implies that the exchange rate is determined by the demand for and supply of foreign exchange. It is also regarded as the money market principle. The argument points out that the currency differential ultimately corresponds to the balance of payment status of the country in question. A positive balance of payments contributes to an increase in the currency's intrinsic value. Unfavorable balance of payments triggers an asset value loss.

\subsection{Empirical Review}

Several empirical studies abounds on exchange rate volatility or stability around the world. Ayekple (2015) examined the nature of volatility of Naira/Dollar exchange rates in Nigeria using several variants of GARCH models on monthly data from January 1970 to December 2007. The results of the study show that all the GARCH family models indicate evidence of volatility persistent Naira/Dollar exchange rates. The findings are similar for both the fixed exchange rate and managed float rate regimes.

Obansa, Eze and Okolie (2013) analysed Pakistan Rupee/US dollar exchange rates using symmetric GARCHM $(1,1)$ with the other two asymmetric models EGARCH $(1,1)$ and TARCH $(1,1)$ on daily and monthly data for the period January 2001 to December 2009. The results of the GARCH-M $(1,1)$ model show evidence of volatility clustering. The results of asymmetric EGARCH $(1,1)$ model show evidence of asymmetric effects, where positive and negative news have a different impact on volatility progression. The TARCH $(1,1)$ model results also provide support for the asymmetric behaviour in both the daily and monthly exchange rate returns in Pakistan.

Harris (2015) examined the daily returns of exchange rates series of nineteen Arab countries using two symmetric and asymmetric univariate specifications of the generalized autoregressive models, for the period ranging from January 1, 2000, to November 19, 2011. The currencies considered are the United Arab Emirates dirham, Bahraini Dinar, Djiboutian Franc, Algerian Dinar, Egyptian pound, Iraqi Dinar, Kuwaiti Dinar, Lebanese Pound, Libyan Dinar, Moroccan Dirham, Mauritanian Ouguiya, Omani Rial, Qatari Riyal, Saudi Arabian Riyal, Somali Shilling, Syrian Pound, Tunisian Dinar and Yemeni Rial, all against the US dollar. The results of the symmetric GARCH $(1,1)$ model show that while volatility is an explosive process for the ten of nineteen currencies, it is quite persistent for seven currencies. The results of the asymmetric EGARCH $(1,1)$ model show evidence of leverage effects for all currencies, except for the Jordanian Dinar, indicating that negative shocks imply higher next period volatility than positive shocks of the same magnitude. The study concludes that the exchange rate volatility can be adequately modeled using GARCH family models.

Frimpong and Amevialor (2015) modeled daily exchange rates of the Gambian Dalasi against the Euro and US dollars from May 2003 through May 2013 by applying autoregressive moving average (ARMA) and generalized conditional heteroscedasticity (GARCH 1,1). The empirical results of the study show, among others, that the sum of $\mathrm{ARCH}$ and GARCH parameters are very close to one. The study concludes that the volatility in the Gambian foreign exchange market is highly persistent and that the distribution of the return series is heavytailed.

Anyawu (2014) conducted an empirical analysis of the volatility of the exchange rate of US Dollar/Mauritian Rupee (USD/MUR) using various GARCH-type models using daily data over the period January 2004 to June 2015. Specifically, he compared the predictive ability of the symmetric GARCH model with the asymmetric EGARCH, TGARCH, PGARCH and GJR-GARCH models. The results indicate, among others, that the USD/MUR exchange rate series exhibit volatility persistence as well as the stylised features, volatility clustering, and leverage effects; hence supporting the implementation of the asymmetric models. The results also show the suitability of asymmetric GARCH-type models in predicting the volatility of USD/MUR exchange rates.

Okoli (2014) examines optimal exchange-rate policy in two-country, he used sticky-price general equilibrium models in which households and firms optimize over an infinite horizon in an environment of uncertainty. The models are in the vein of the "new open-economy macroeconomics" as exemplified by Obstfeld and Adetoba (2015). The conditions under which fixed or floating exchange rates yield higher welfare, or the optimal foreign exchange intervention rule, depend on the exact nature of price stickiness and on the degree of risk-sharing opportunities. The study provides some preliminary empirical evidence on the behavior of consumer prices in Mexico that suggests failures of the law of one price are important. The evidence on price setting and risk-sharing opportunities are not refined enough to make definitive conclusions about the optimal exchange-rate regime for that country. 
Adeleke, (2015) shows in its study of optimal exchange rate determination that there is no such thing as the optimal or best exchange rate policy. It all depends on the underlying fundamentals, which may be both domestic and external, as well as perceptions of policy credibility. How countries react to them will not be the same at all. Floating the currency would, of course, be deemed to be better than the other approaches but questions need to be answered as to, among others, whether the country has sufficient reserves to intervene in the market at all times when it is necessary. In the case of Malawi, this has proved to be very difficult since the availability of foreign exchange is highly seasonal. He concludes that Malawi also faces another problem in that public confidence in the floating regime is taking rather long to stabilize with the consequence that the kwacha is constantly under speculative attacks.

Balogun (2015) examines the role of structural factors in Mexican real exchange rate experience since 1970, particularly in the crisis of December 1994. He finds that fundamental determinants of the real exchange-omitted from previous research are co integrated with nominal exchange rates and relative prices, while tests of PPP (Purchasing Power Parity) alone fail. The co integrating equation indicates a severe undervaluation during the 1980 s and only modest overvaluation in the period immediately preceding the devaluation in December 1994. The author concludes that nothing in the fundamentals can account for the magnitude of the blow Mexico suffered at that time.

Adelowokan (2015) investigates the proper exchange rate system that serves the main macroeconomic goals within increasing integrated global financial markets. The major findings of the study are that it is unrealistic to assume that one exchange rate regime is the best for all circumstances and for all countries; The choice of pegging the currency to another currency or a basket of currencies depends on the degree of trade concentration with another country (country B) and the currency in which the country's (country A) foreign debt is mostly denominated, and the managed float or free float system is more realistic for a country highly integrated into global financial markets.

\section{METHODOLOGY}

Ex post-facto and correlation research designs are employed for this study. The justification for using ex-post factor research design (after the fact) design is that the source of data is historical in nature. That is, the study tends to adopt existing data rather than new data specifically gathered for the study. The research design adopted for the purpose of this study was longitudinal, which considered the effect of Bureau de changes establishments on the exchange rate volatility of the Nigerian Naira over the period under review. Precisely, the research design used was a trend which focused on the relationship between exchange rate volatility of the Naira and Bureau De Change establishment in Nigeria. The trend research design was adopted for this study because the results of trend analysis are easily verifiable. Additionally, results from trend analysis are always very close to accurate. Trend analysis can be simulated, confirmed and adjusted as necessary. The population of this study covers Nigeria's exchange rates from 1989, when the Bureau de Change was licensed by the CBN, to 2018. However, this study limits its scope using sample data collected on the bureau de change and exchange rate of the Naira for the period between 2008 and 2018. This study relied on data collected from secondary sources. Data on the exchange rate and bureau de change establishment was collected from the Central Bank of Nigeria $(\mathrm{CBN})$ statistics database.

\subsection{Model Specification}

The following model is based on the null hypotheses that capture the objectives of the study is to mainly investigate if there is a correlational relationship between bureau de change and exchange rate of the Naira.

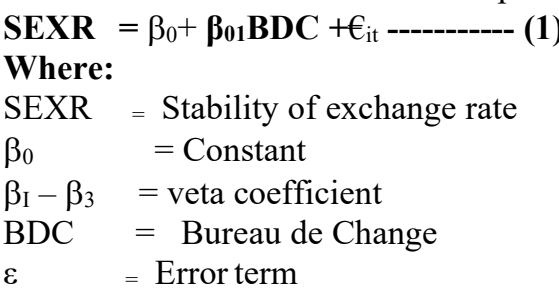

\subsection{A priori Expectation for the Models}

Table 2: Apriori expectation for the models

\begin{tabular}{|l|l|l|}
\hline Dependent variable & Independent Variable & $\begin{array}{l}\text { Relationship between Dependent and } \\
\text { Independent Variable }\end{array}$ \\
\hline Exchange rate & Bureau de change & Positive \\
\hline
\end{tabular}

\section{Source: Authors compilation}

\section{RESULTS AND ANALYSIS}

This section presents the analysis and interpretation of the results obtained from the data collected for the study. The descriptive and inferential statistics of the data collected for the study are presented, discussed and interpreted. 
The section begins with the discussion of the descriptive statistics of the data collected, and then the correlation matrix of Bureau De change and stability of exchange rate. The interpretation of the regression results and test of hypotheses of the study are then conducted.

Table 3. Descriptive Statistics

\begin{tabular}{|l|l|l|l|l|}
\hline Variable & Min & Max & Mean & Std. Dev. \\
\hline Bureau De Change & -0.1241 & 0.22652 & 0.02127 & 0.04154 \\
\hline EXR & 0.35 & 0.9375 & 0.63192 & 0.1233 \\
\hline
\end{tabular}

Source: STATA 9.1 Output

Table 3 reveals that the mean value for Bureau De change over the period is 0.02127 while that of the exchange rate is 0.63192 . The minimum value for $\mathrm{BDC}$ is -0.1241 while the minimum Exchange rate over the period is 0.35 . The maximum observation of BDC is 0.22652 while the maximum observation of EXR is 0.9375 . The standard deviation of Bureau de change was 0.04154 while that of the exchange rate was 0.1233.

\section{Correlation Matrix Analysis}

The correlation analysis measures the degree of association between the variables i.e. when the bureau de change establishment will improve the exchange rate in Nigeria. Table 4 presents the correlation results for the independent variable which is Bureau de change establishment and the dependent variable which is the exchange rate.

$\mathrm{H}_{01}=$ There is no significant correlational relationship between the stability of exchange rate and bureau de change establishment in Nigeria.

Table 4. Correlation Matrix Results

\begin{tabular}{|l|l|l|}
\hline VARIABLE & BDC & EXR \\
\hline Bureau De Change Establishment & 1.0000 & \\
\hline EXR & 0.3293 & 1.0000 \\
\hline P value & 0.352818 & \\
\hline
\end{tabular}

\section{Source: STATA 9.1 Output}

In this section, the Pearson correlation Coefficients of the variables of the study are presented in Table 3 , from this table, it is shown that the independent variable Bureau De Change establishment is positively related to exchange rate. The result based on the $p$ value of 0.352818 shows that the correlation coefficient of 0.352818 is not significant. Hence, we fail to reject the null hypothesis that there is no significant correlational relationship between Bureau De change and the stability of the exchange rate.

Regression Analysis

This section presents and analyses the regression results of the models of the study. The section begins with the analysis of the model. This table presents the regression result of the dependent variable exchange rate stability and the independent variables of the study Bureau De change establishment. The null hypothesis of the regression analysis is stated below:

$\mathrm{H}_{02}=$ There is no significant causal relationship between the stability of exchange rate and bureau de change establishment in Nigeria

Table 4: Regression Result

\begin{tabular}{|l|l|l|l|}
\hline Variable & Coefficient & t-values & P-values \\
\hline Constant ( $\boldsymbol{\alpha})$ & $\mathbf{0 . 0 4 1 8 0 5 3}$ & $\mathbf{0 . 8 7}$ & $\mathbf{0 . 3 8 6}$ \\
\hline BDC & $\mathbf{0 . 0 8 9 7 4 7 0}$ & $\mathbf{2 . 2 6}$ & $\mathbf{0 . 0 2 7}$ \\
\hline $\mathbf{R}^{2}$ & $\mathbf{0 . 1 7 4 5}$ & & \\
\hline Adjusted R & $\mathbf{0 . 1 3 9 6}$ & & \\
\hline F-Stat. & $\mathbf{5 . 0 0}$ & & \\
\hline F-sig & $\mathbf{0 . 0 0 3 3}$ & & \\
\hline
\end{tabular}

\section{Extracted from STATA 9.1 Output}

A low p-value of 0.027 which is less than 0.05 thus indicating that the null hypothesis should be rejected. Tvalue of 2.26 is greater than the threshold of 2, which indicates that the coefficient of 0.0897470 is significant at $95 \%$ confidence interval. Therefore, we reject the null hypothesis that there is no significant causal relationship between the stability of the exchange rate and the exchange rate. The $\mathrm{R}^{2}$ at 0.1745 shows that there is a positive although the weak relationship between the Bureau de changes the establishment and stability of the exchange rate.

\section{DISCUSSION OF FINDINGS AND CONCLUSION}

\subsection{Discussion of Findings}

From the above result presented, it is obvious that the Bureau De change significantly determines the exchange rate. It was discovered that the bureau de change establishment impact the stability of the exchange rate in Nigeria. The exchange rates charged at the bureau are generally correlated with the spot prices accessible for large interbank 
transactions and are accustomed to ensure a profit. The rate at which a bureau will buy currency varies from that at which it will sell it; for every currency, it trades both will be on display, generally in the shop window. This is supported by the study of Chamalwa and Idris (2016).

\subsection{Conclusion}

Many researchers have carried out empirical studies exchange rate volatility to financial growth especially for developing countries using different approaches (Ajao et al, 2017). The exchange rate stability and sometimes prediction is one of the demanding applications of modern concern in Nigeria owing to the existence of Bureau De Change outfits in the major cities. Over the years, the rates are inherently noisy, non - stationary and deterministically chaotic, as they are often influenced similar unstable factors (Erdogan \& Goksu, 2014). As one of the major roles of monetary authorities is to prevent divergence between the official exchange rates and secondary exchange rates in the economy, this study concluded that the bureau de change establishment influences the stability of the exchange rate.

The study findings reveal that Nigeria practiced a fixed exchange rate before 1986, but later adopted a flexible exchange rate policy. As a result, the official currency (Naira) exchange rate was allowed to float, within a prespecified band, in relation to other currencies thereby allowing changes within the band to be determined by market forces of demand and supply. Some of the policies employed to ensure exchange rate stability include: second-tier foreign exchange market, bureau de change, autonomous foreign exchange market, inter-bank foreign exchange market, the enlarged foreign exchange market, and Dutch auction system (DAS) that includes the retail and wholesale. The ineffectiveness of each of these policies to achieve sustainable stability in the Nigerian exchange rate led to the adoption of several other policies. This suggests that, on aggregate, the establishment of Bureau de Change has had the most tremendous influence on the stability of exchange rates in Nigeria in recent times..

\section{Acknowledgements:}

This research article was carried out as part of contribution by the authors as a follow-up to improve and inject new thinking the changing financial policy in Nigeria. While no special funding or grant to support this study, the article it expected to open areas of further contribution to literature and its relevance to current issues in finance theory and practice.

\section{Reference}

Adelowokan, O. A., Adesoye, A. B \& Balogun, O. D (2015) Exchange rate volatility on investment and growth in Nigeria, an empirical analysis, Global Journal of Management and Business Research, 15 (10): $20-30$.

Adeoye, B. W \& Saibu, O. M (2014). Monetary policy shocks and exchange rate volatility in Nigeria, Asia Economic and Financial Review, 4 (4): 544 - 562.

Ajao, I. O., Obafemi, O. S \& Bolarinwa, F. A (2017). Modeling Dollar - Naira exchange rate in Nigeria, Nigeria Statistical Society, 1 (2017): $191-198$.

Ali, A. I., Ajibola, I. O., Omotosho, B. S., Adetoba, O. O \& Adeleke, A. O (2015). Real exchange rate misalignment and economic growth in Nigeria, CBN Journal of Applied Statistics, 6 (2): 103 - 131.

Anigbogu, T. U., Okoye, P. V. C., Anyawu, N. K \& Okoli, M. I (2014). Real exchange rate movement misalignment and volatility and the agricultural sector: evidence from Nigeria, American International Journal of Contemporary Research, 4 (7): 133 - 141.

Ayekple, Y. E., Harris, E Frimpong, N. K \& Amevialor, J (2015). Time series analysis of the exchange rate of the Ghananian Cedi to the American Dollar, Canadian Center of Science and Education - Journal of Mathematics Research, 7 (3): 46 - 53.

Babu, A. S \& Reddy, S. K (2015). Exchange rate forecasting using ARIMA, Neural Network and Fuzzy Neuron, Journal of Stock \& Forex Trading, 4 (3): $01-05$.

Bakare, A. S (2011). The consequences of foreign exchange rate reforms on the performances of private domestic investment in Nigeria, International Journal of Economics and Management Sciences, 1 (1): 25 - 31.

Basu, K \& Varoudakis, A (2013). How to move the exchange rate if you must: the diverse practice of foreign intervention by central banks and a proposal for doing it better, Working Paper No. 6460

Belke, A \& Gros, D (2001). Designing EU - US Atlantic monetary relations: exchange variability and labour markets, The World Economy, 25 (2001): 789 - 813.

CBN, (2015). Further liberalization \& development of the foreign exchange market. Retrieved from. http://www.cenbank.org/IntOps/.

Chamalwa, H. A., Rann, H. B \& Idris, I. M (2016). Modeling of Nigerian foreign exchange (Naira/1.0\$) using disbursement data (1981 - 2010), The International Journal Of Humanities \& Social Studies, 4 (8): 34 - 40.

Chi, X., Zhou, M \& Wang, G (2015). Forecasting RMB exchange rate based on a Nonlinear Combination Model of ARFIMA, SVM and BPNN, Hindawi Publishing Corporation - Mathematical Problems in Engineering, 2015 (635345): $1-10$ 
Dayyabu, S., Adnan, A. A \& Sulong, Z (2016) Effectiveness of foreign exchange market intervention in Nigeria (1970 - 2013), EJ Econ Journals - International Journal of Economics and Financial Issues, 6 (1): 279 - 287.

Erdogan, O \& Goksu, A (2014) Forecasting Euro and Turkish Lira exchange rates with Artificial Neural Networks (ANN), HRMARS - International Journal of Academic Research in Accounting, Finance and Management Sciences, 4 (4): $307-316$.

Emenike, K. O., \& Aleke, S. F. (2012) Modeling asymmetric volatility in the Nigerian stock exchange. European Journal of Business and Management, 4(12), 52-60.

Eze, E \& Okpala, O (2014). Quantitative analysis of the impact of exchange rate policies on Nigeria's economic growth: a test of stability of parameter estimates, International Journal of Humanities and Social Science, 4 (7): $265-272$.

Krueger, Anne O. (1969) “Balance-of-Payments Theory.” Journal of Economic Literature, 7(1), pp. 1-26.

Mohammed, M. B \& Abdulmuahymin, S. A (2016). Modeling the exchange rate Stability of Nigerian currency (Naira) with respect to US Dollar, International Journal of Scientific \& Engineering Research, 7 (7): $86-$ 104.

Musa, Y., Tasiu, M \& Abubakar B (2014). Forecasting exchange rate volatility between Naira and US dollar using GARCH models, International Journal of Academic Research in Business and Social Sciences, 4 (7): 369 381.

ni, T \& Bonga, W. G (2017f). An Empirical Analysis of the Determinants of Private Investment in Zimbabwe, Dynamic Research Journals - Journal of Economics and Finance (DRJ - JEF), 2 (4): 38 - 54.

Nyahokwe, O \& Ncwadi, R (2013). Impact of exchange rate volatility on unemployment in South Africa, MCSER Publishing - Mediterranean Journal of Social Sciences, 4 (3): $109-120$.

Obansa, S. A. J., Okoroafor, O. K. D., Aluko, O. O \& Eze, M (2013). Perceived relationship between exchange rate, interest rate and economic growth in Nigeria: 1970 - 2010, American Journal of Humanities and Social Sciences, 1 (3): $116-124$

Oleka, C. D \& Okolie, P. I. P (2016). The impact of floating exchange rate regime on economic growth in Nigeria (1986 - 2015), IOSR Journal of Economics and Finance (IOSR - JEF), 7 (5): 35 - 42.

Oleka, C.D., Sabina, E. A \& Mgbodile, C. C. I (2014). Empirical Analysis of the Relationship Between Foreign Exchange Rate and Economic Growth in a Developing Economy: Nigerian Experience, World Journal of Management and Behavioral Studies, 2 (2): $28-36$.

Taiwo, O \& Adesola, O. A (2013). Exchange rate volatility and bank performance in Nigeria, Asian Economic and Financial Review, 3 (2): 178 - 185. http://aessweb.com/journal-detail.php?id=5002

Tindaon, S (2015). Forecasting the NTD/USD exchange rate using Autoregressive Model, Department of International Business, CYCU, Taiwan.

Uddin, K. M. K., Rhaman, M. M \& Quasar, G. M. A. A (2014). Causality between exchange rate and economic growth in Bangladesh, European Scientific Journal, 10 (31): $11-26$.

Usman, O. A \& Adejare, A. T (2013). Effect of exchange rate volatility on Nigerian economy (1991 - 2000), International Journal of Academic Research in Economics and Management Sciences, 2 (6): 172 - 184.

Yokoyamal, I., Higa, K \& Kawaguchi, D (2015) The effect of exchange rate fluctuations on employment in a segmented labor market, Research Institute of Economy, Trade and Industry (RIETI). 